\title{
Activator-free palladium-catalyzed silylation of aryl chlorides with silylsilatranes
}

\section{AUTHOR(S):}

Yamamoto, Yutaro; Matsubara, Hiroshi; Murakami, Kei; Yorimitsu, Hideki; Osuka, Atsuhiro

\section{CITATION:}

Yamamoto, Yutaro ...[et al]. Activator-free palladium-catalyzed silylation of aryl chlorides with silylsilatranes. Chemistry - An Asian Journal 2015, 10(1): 219-224

\section{ISSUE DATE:}

2015-01

URL:

http://hdl.handle.net/2433/218332

\section{RIGHT:}

This is the accepted version of the following article: YYamamoto, Y., Matsubara, H., Murakami, K., Yorimitsu, H. and Osuka, A. (2015), Activator-Free Palladium-Catalyzed Silylation of Aryl Chlorides with Silylsilatranes. Chem. Asian J., 10: 219-224.], which has been published in final form at https://doi.org/10.1002/asia.201402595. This article may be used for non-commercial purposes in accordance with Wiley Terms and Conditions for Self-Archiving.; この論文は出版社版 でありません。引用の際には出版社版をご確認ご利用ください。;This is not the published version. Please cite only the published version. 


\title{
Activator-Free Palladium-Catalyzed Silylation of Aryl Chlorides with Silylsilatranes
}

\author{
Yutaro Yamamoto, ${ }^{[a]}$ Hiroshi Matsubara, ${ }^{*[b]}$ Kei Murakami, ${ }^{[a, c]}$ Hideki Yorimitsu, ${ }^{*[a, d]}$ and Atsuhiro \\ Osuka $^{[a]}$ \\ Dedication ((optional))
}

\begin{abstract}
Palladium-catalyzed silylation of aryl chlorides with silylsilatranes 1 proceeds under activator-free conditions, hence displaying wide functional group compatibility to allow boryl and siloxy groups to survive. Experimental and computational studies have revealed that smooth transmetalation from silylsilatranes to arylpalladium chloride is facilitated by strong interaction between the Lewis acidic silicon and the chloride.
\end{abstract}

\section{Introduction}

Due to the important roles that organosilicon compounds play in organic chemistry, chemists have devoted much time to develop new efficient reactions for carbon-silicon bond formation. ${ }^{[1]}$ Since the conventional nucleophilic attack of chlorosilanes with organomagnesium or -lithium reagents suffers from functional group compatibility, ${ }^{[2]}$ silylation under milder conditions have been drawing significant attention. ${ }^{[12,3-12]}$ Among them, transition-metal-catalyzed silylation of aryl halides with disilanes represents an attractive tool (Scheme 1, left). ${ }^{[4-6,11,12]}$ However, the silylation with disilane generally requires very high temperatures such as $140-170{ }^{\circ} \mathrm{C}^{[4]}$ or highly basic reaction conditions. ${ }^{[6]}$ Milder protocols for achieving efficient silylation with wider functional group compatibility are therefore highly sought after.

Palladium-catalyzed silylation with disilane consists of oxidative addition of aryl halide to palladium(0), transmetalation between arylpalladium halide and disilane, and reductive elimination. Taking the low reactivity of disilanes into consideration, one should focus on the transmetalation step to

[a] Y Yamamoto, Dr. K. Murakami, Prof. Dr. H. Yorimitsu, Prof. Dr. A Osuka

Department of Chemistry, Graduate School of Science

Kyoto University

Sakyo-ku, Kyoto 606-8502, Japan

E-mail: yori@kuchem.kyoto-u.ac.jp

[b] Prof. Dr. H. Matsubara

Department of Chemistry, Graduate School of Science

Osaka Prefecture University

Naka-ku, Sakai 599-8531, Japan

E-mail: matsu@c.s.osakafu-u.ac.jp

[c] Dr. K. Murakami

The Hakubi Center for Advanced Research

Kyoto University

Sakyo-ku, Kyoto 606-8502, Japan

[d] Prof. Dr. H. Yorimitsu

ACT-C, JST

Sakyo-ku, Kyoto 606-8502, Japan

Supporting information for this article is given via a link at the end of the document.((Please delete this text if not appropriate)) achieve activator-free mild silylation. ${ }^{[5,13]}$ To this end, we designed unsymmetrical disilane, silylsilatrane 1 (Scheme 1, right). We initially envisioned that internal coordination of the nitrogen atom should facilitate $\mathrm{Si}-\mathrm{Si}$ bond cleavage for facile transmetalation. ${ }^{[14-16]}$ Indeed, in the literature, arylstannatranes and -germatranes are known to be more reactive in activatorfree cross-coupling reactions than the corresponding trialkyl analogs. ${ }^{[15]}$ We also expected that the silatrane moiety of 1 would be still more Lewis acidic than a triorganosilyl group to realize efficient interaction with halide on palladium for both smooth transmetalation and selective transfer of the triorganosilyl group of 1 .
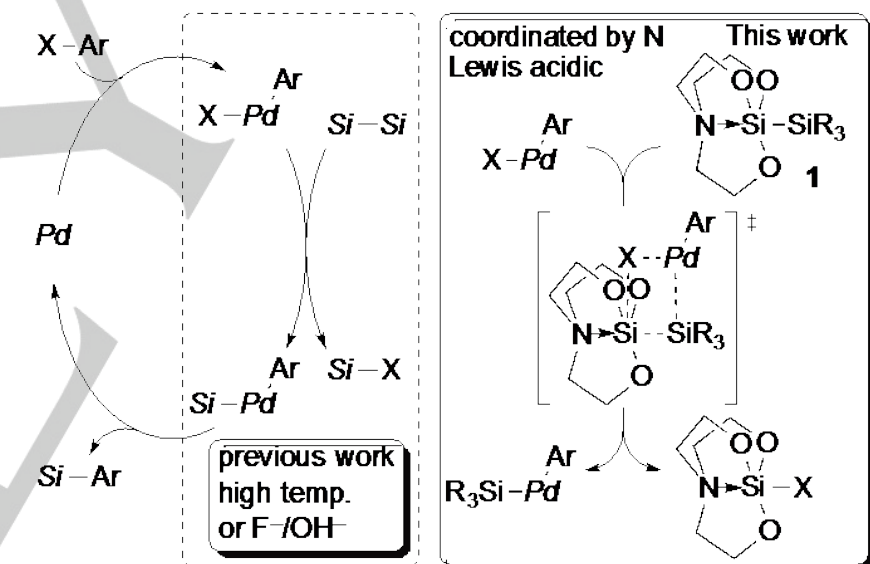

Scheme 1. Catalytic Cycle for Pd-catalyzed Silylation with Disilane and Our Design of Silylsilatrane 1.

\section{Results and Discussion}

Synthesis of 1 was easy and scalable (See Experimental Section). For instance, nucleophilic substitution reaction of readily available ethoxysilatrane with dimethylphenylsilyllithium afforded dimethylphenylsilylsilatrane (1a) on a 12-g scale (Figure 1). Silylsilatranes $\mathbf{1}$ are fairly stable and can be stored in air for more than one year without detectable decomposition. Therefore, silylsilatranes $\mathbf{1}$ have a practical advantage over the corresponding simpler trialkoxydisilanes such as $\mathrm{R}_{3} \mathrm{Si}-$ $\mathrm{Si}(\mathrm{OMe})_{3}{ }^{[17]} \mathrm{X}$-ray crystallographic analysis of $\mathbf{1 a}$ (Figure 1) revealed that the length of the Si-Si bond $(2.3426(9) \AA)$ is close to that of a typical symmetrical disilane (2.354(2) $\AA$ for $\left.\left(\mathrm{FpCH}_{2}\right) \mathrm{Me}_{2} \mathrm{Si}-\mathrm{SiMe}_{2}\left(\mathrm{CH}_{2} \mathrm{Fp}\right)\left(\mathrm{Fp}=\left(\eta^{5}-\mathrm{C}_{5} \mathrm{H}_{5}\right) \mathrm{Fe}(\mathrm{CO})_{2}\right)\right)^{[18]}$ This similarity indicates that the transannular coordination of the nitrogen atom to the bridgehead silicon is not so effective as to 
elongate the $\mathrm{Si}-\mathrm{Si}$ bond despite a short transannular $\mathrm{N}-\mathrm{Si}$ distance of 2.153(2) $\AA$.

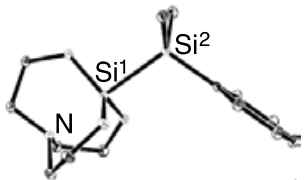

Figure 1. Synthesis and ORTEP Drawing of Silylsilatrane 1a. Thermal ellipsoids represent $50 \%$ probability.

With silylsilatrane 1 in hand, we examined silylation of aryl halides under palladium catalysis. To our delight, the reaction of electron-rich aryl chloride with $1 \mathbf{a}$ proved to proceed at $100{ }^{\circ} \mathrm{C}$ under $\mathrm{Pd}_{2}(\mathrm{dba})_{3} / \mathrm{SPhos}^{[19]}$ catalysis in the absence of an additive (Table 1, entries 1-5). As we expected, the dimethylphenylsilyl group of 1a was selectively transferred and none of arylsilatranes were detected. Under the fluoride-free conditions, a siloxy group was naturally compatible (entry 2 ). Arylsilane $\mathbf{2 d}$ bearing a substituent at the ortho position was obtained in good yield after $30 \mathrm{~h}$ (entry 4). Unfortunately, the $\mathrm{Pd}_{2}(\mathrm{dba})_{3} /$ SPhos catalysis did not work for the reaction of electron-deficient aryl chlorides (entry 7). After rescreening of catalysts, $\mathrm{Pd}\left(\mathrm{PtBu}_{3}\right)_{2}{ }^{[20,21]}$ showed an excellent catalytic activity in converting electron-deficient aryl chlorides (entries 8-11). Notably, the chloro group of 4-chlorophenylboronate was substituted with the silyl group with the boronate moiety intact (entry 12). Both catalytic systems are effective in silylating electronically neutral chlorotoluenes (entries 6, 13, and 14).

The scope of silylsilatrane 1 was surveyed (Table 2). Bulkier silyl groups were transferred efficiently (entries 1 and 2). Trimethylsilylsilatrane (1d) was less reactive yet participated in the silylation with the aid of RuPhos ${ }^{[19]}$ at a higher temperature in DMF. The silatrane skeleton of $\mathbf{1}$ is important for efficient silyl transfer: simple hexaorganodisilane and monoalkoxydisilane reacted sluggishly (entries 4 and 5).

Surprisingly, attempts to silylate aryl bromide and triflate failed and resulted in the recovery of the starting material under the standard conditions (Scheme 2, eq 1). ${ }^{[22]}$ Considering that oxidative addition of aryl bromide and triflate should be much easier than that of aryl chloride, we speculated that the transmetalation step would be problematic and that chloride on palladium would play a crucial role in smooth transmetalation. Indeed, lithium chloride as an additive promoted the silylation (eqs 2 and 3), probably through halide ligand exchange between arylpalladium bromide or triflate and lithium chloride. We confirmed this ligand exchange process by ${ }^{31} \mathrm{P}$ NMR analysis (See Supporting Information).
Table 1. Silylation of Aryl Chlorides with Silylsilatrane 1a<smiles>[R]c1cccc(Cl)c1</smiles>
no additive toluene, $100{ }^{\circ} \mathrm{C}$ 1.2 equiv

\begin{tabular}{|c|c|c|c|c|}
\hline entry & $\mathrm{R}$ & Condt. ${ }^{[a]}$ & 2 & Yield [\%] \\
\hline 1 & 4-MeO & A & $2 a$ & 89 \\
\hline 2 & 4-TBDMSO & A & $2 b$ & 91 \\
\hline $3^{[\mathrm{b}]}$ & 4-AcHN & A & 2c & 78 \\
\hline $4^{[c]}$ & 2-MeO & & $2 d$ & 71 \\
\hline $5^{[\mathrm{d}]}$ & (3-chlorothiophene) & A & $2 e$ & 74 \\
\hline 6 & $4-\mathrm{CH}_{3}$ & A & $2 f$ & 77 \\
\hline 7 & $4-\mathrm{CF}_{3}$ & $A$ & $2 g$ & $0^{[g]}$ \\
\hline 8 & $4-\mathrm{CF}_{3}$ & $\mathrm{~B}$ & $2 g$ & 99 \\
\hline 9 & $4-\mathrm{CO}_{2} \mathrm{Et}$ & B & $2 \mathrm{~h}$ & 96 \\
\hline 10 & $3-\mathrm{CN}$ & B & $2 \mathbf{i}$ & 96 \\
\hline $11^{[\mathrm{e}]}$ & $3-\mathrm{NO}_{2}$ & B & $2 j$ & 71 \\
\hline $12^{[f]}$ & 4-Bpin & B & $2 k$ & 69 \\
\hline $13^{[f]}$ & $3-\mathrm{CH}_{3}$ & $\mathrm{~B}$ & 21 & 71 \\
\hline 14 & $4-\mathrm{CH}_{3}$ & B & $2 f$ & 77 \\
\hline
\end{tabular}

[a] condt. A: $3 \mathrm{~mol} \% \mathrm{Pd}_{2} \mathrm{dba}_{3}, 9 \mathrm{~mol} \%$ SPhos, $12 \mathrm{~h}$; condt. B: $5 \mathrm{~mol} \%$ $\mathrm{Pd}\left(\mathrm{PtBu}_{3}\right)_{2}, 10$ h. [b] 1.0 equiv 1a. [c] 30 h. [d] 8 h. [e] 40 h. [f] $10 \mathrm{~mol} \%$ catalyst. $[\mathrm{g}]>90 \%$ recovery of the starting material.

Table 2. Scope of Disilane

\begin{tabular}{|c|c|c|c|c|}
\hline & M & $\begin{array}{l}\text { condt. A } \\
1.2 \text { equiv disilane }\end{array}$ & . & \\
\hline entry & Disilane & & Product & Yield [\%] \\
\hline 1 & & $\mathrm{SiMePh}_{2}(\mathbf{1 b})$ & 3 & 81 \\
\hline $2^{[a]}$ & $\mathrm{N} \mathrm{Si}_{1}-\mathrm{SiR}_{3}$ & $\mathrm{SiMe}_{2}(0$-tolyl) (1c) & 4 & 90 \\
\hline $3^{[\mathrm{b}]}$ & & $\mathrm{SiMe}_{3}(\mathbf{1 d})$ & 5 & $54\left(74^{[\mathrm{c}]}\right)$ \\
\hline 4 & $\mathrm{Me}_{2} \mathrm{PhSi}-\mathrm{Si}$ & $\mathrm{Me}_{2} \mathrm{Ph}$ & $2 a$ & 11 \\
\hline 5 & $(\mathbb{P r O}) \mathrm{Me}_{2} \mathrm{Si}$ & $-\mathrm{SiMe}_{2} \mathrm{Ph}$ & $2 a$ & 16 \\
\hline
\end{tabular}

[a] $5 \mathrm{~mol} \% \mathrm{Pd}_{2}(\mathrm{dba})_{3}$ and $15 \mathrm{~mol} \%$ SPhos. [b] RuPhos was used instead of SPhos. Performed in DMF at $120^{\circ} \mathrm{C}$. [c] NMR yield. 


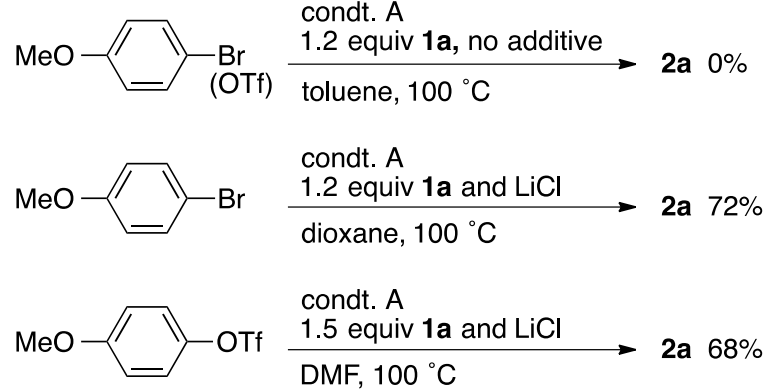

Scheme 2. Silylation of Aryl Bromide and Triflate.

To investigate the effect of the chloride ligand in the smooth transmetalation, DFT calculations were performed by using Gaussian 09. ${ }^{[23,24]}$ We chose transmetalation between $\mathrm{PhPdX}\left(\mathrm{PtBu}_{3}\right)$ and trimethylsilylsilatrane (1d) as a model reaction for computational simplicity (Figure 2 ). Transmetalation between $\mathrm{PhPdCl}\left(\mathrm{PtBu}_{3}\right)$ and $\mathbf{1 d}$ was calculated to proceed via a four-membered transition state $\mathbf{T S} \mathbf{C l}$ in a concerted manner with an activation barrier of $98.7 \mathrm{kJmol}^{-1}$. The transmetalation results in formation of Prod_Cl, in which the chloride weakly coordinates to palladium. The overall reaction is slightly endothermic by $14.7 \mathrm{kJmol}^{-1}$. On the other hand, the activation energy for transmetalation between $\mathrm{PhPdBr}\left(\mathrm{PtBu}_{3}\right)$ and $\mathbf{1 d}$ was calculated to be $114.1 \mathrm{kJmol}^{-1}$ and $\mathbf{T S} \_\mathrm{Br}$ is more difficult to reach by $15.4 \mathrm{kJmol}^{-1}$ than TS_Cl. The formation of product Prod_Br is significantly endothermic $\left(44.2 \mathrm{kJmol}^{-1}\right)$, which correlates with late transition state $\mathbf{T S} \mathbf{B r}$ with the higher activation energy. These results show that the efficient silylation of aryl chloride is based on intrinsically strong interaction between silicon and chlorine in the transmetalation. ${ }^{[25,26]}$

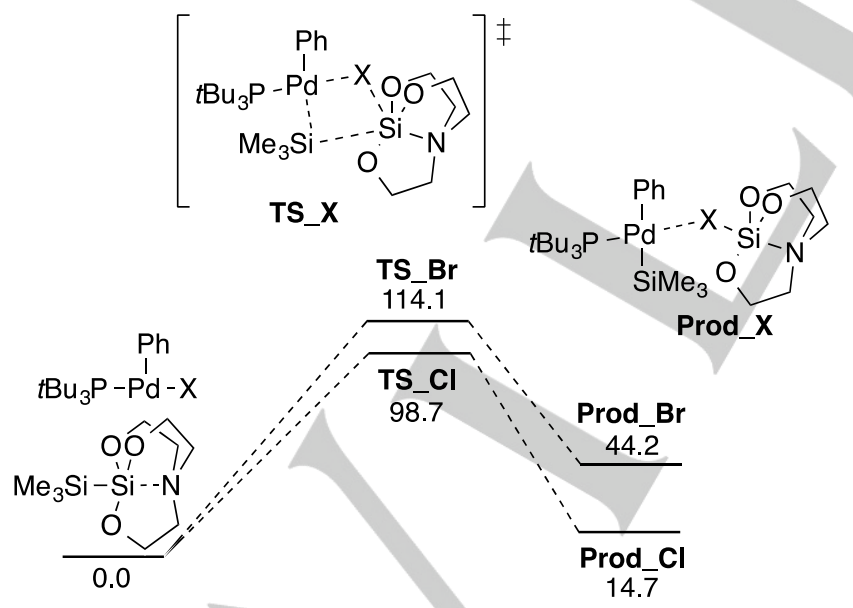

Figure 2. Energy profile of transmetalation obtained by DFT calculations at the $\mathrm{M06} / 6-311 \mathrm{G}^{* *}+\mathrm{ECP}(\mathrm{Pd}, \mathrm{P}, \mathrm{Si}, \mathrm{Cl}, \mathrm{Br})$ level. Energies are in $\mathrm{kJmol}^{-1}$.

\section{Conclusions}

We have developed silylsilatranes as promising silylating agents in palladium-catalyzed silylation of aryl chlorides under activatorfree conditions. A variety of functional groups such as boryl and siloxy groups are tolerant due to the absence of a basic activator. Experimental and computational investigations have revealed that the success of the activator-free silylation relies on smooth transmetalation between arylpalladium chloride and silylsilatranes, which takes advantage of the affinity between the chloride on the palladium and the Lewis acidic silicon. These findings contain important information about still unexplained transmetalation in general, and have significant impacts on development of new activator-free reactions of moderately reactive organometalloid reagents of low toxicity, which are underway in our laboratory to realize ultimate activator-free cross-coupling reactions.

\section{Experimental Section}

${ }^{1} \mathrm{H}$ NMR (600 MHz), ${ }^{13} \mathrm{C}$ NMR (151 MHz), ${ }^{31} \mathrm{P}$ NMR $(243 \mathrm{MHz})$, and ${ }^{29} \mathrm{Si}$ NMR (119 MHz) spectra were taken on a JEOL ECA-600 spectrometer. Chemical shifts were reported as delta scale in ppm relative to $\mathrm{CHCl}_{3}(\delta$ $=7.26)$ for ${ }^{1} \mathrm{H}$ NMR, to $\mathrm{CDCl}_{3}(\delta=77.16)$ for ${ }^{13} \mathrm{C} \mathrm{NMR}$, to $\mathrm{H}_{3} \mathrm{PO}_{4}(\delta=$ $0.00)$ for ${ }^{31} \mathrm{P} \mathrm{NMR}$, and to tetramethylsilane $(\delta=0.00)$ for ${ }^{29} \mathrm{Si} \mathrm{NMR}$. Spectroscopic grade solvents were used for all spectroscopic studies without further purification. IR spectra were determined on a JASCO IR810. High-resolution APCI-TOF mass spectra were taken on a Bruker microTOF. TLC analyses were performed on commercial glass plates bearing a $0.25-\mathrm{mm}$ layer of Merck Silica gel $60 F_{254}$. Preparative separations were performed by silica gel chromatography (Wako gel C200 , C-300, or C-400). Crystallographic data were collected on a Rigaku RAXIS-RAPID apparatus at $-180{ }^{\circ} \mathrm{C}$ using graphite-monochromated CuK $\alpha$ radiation $(\lambda=1.54187 \AA)$. The structures were solved by direct method (SHELXS-97) and refined with full-matrix least square technique (SHELXL-97). ${ }^{[27]}$

Unless otherwise noted, materials obtained from commercial suppliers were used without further purification. Toluene, $N, N$-dimethylformamide (DMF), and hexamethylphosphoric triamide (HMPA) were distilled from $\mathrm{CaH}_{2}$. Tris(dibenzylideneacetone)dipalladium $\left(\mathrm{Pd}_{2}(\mathrm{dba})_{3}\right)$, SPhos, RuPhos, and lithium wire were purchased from Sigma-Aldrich. $\mathrm{Pd}\left(\mathrm{PtBu}_{3}\right)_{2}$ was purchased from Strem and was stored and weighed in a glove box filled with nitrogen. Anhydrous THF was purchased from Wako Pure Chemical Industries, Ltd. and stored under nitrogen.

Synthesis of Dimethylphenylsilylsilatrane (1a): Ethoxysilatrane ${ }^{[28]}$ $(14.6 \mathrm{~g}, 72 \mathrm{mmol})$ was placed in a reaction flask. The flask was purged with nitrogen, and THF $(120 \mathrm{~mL})$ was added. Dimethylphenylsilyllithium $^{[29]}$ (ca. $1.0 \mathrm{M}$ solution in THF, $72 \mathrm{~mL}, 72 \mathrm{mmol}$ ) was added to the solution via a cannula. The reaction mixture was stirred at room temperature. After $20 \mathrm{~min}$, the reaction was quenched with a saturated $\mathrm{NH}_{4} \mathrm{Cl}$ solution and extracted with EtOAc. The organic layer was washed with brine, dried over anhydrous $\mathrm{Na}_{2} \mathrm{SO}_{4}$, filtered, and concentrated in vacuo to afford white solids. The solids were suspended in hexane $(10 \mathrm{~mL})$ and the suspension was then filtered off. The solids were washed on the filter paper with hexane to afford $1 \mathrm{a}(12.0 \mathrm{~g}, 38.9$ mmol, 54\%). Colorless solid. Mp 164-165 ${ }^{\circ} \mathrm{C}$. IR (neat): 1425,1109 1072, 936, 807, 757, 733, 698, $617 \mathrm{~cm}^{-1} .{ }^{1} \mathrm{H}$ NMR $\left(\mathrm{CDCl}_{3}\right) \delta(\mathrm{ppm}): 7.66-$ $7.63(\mathrm{~m}, 2 \mathrm{H}), 7.31-7.23(\mathrm{~m}, 3 \mathrm{H}), 3.75(\mathrm{t}, \mathrm{J}=5.5 \mathrm{~Hz}, 6 \mathrm{H}), 2.78(\mathrm{t}, \mathrm{J}=5.5$ $\mathrm{Hz}, 6 \mathrm{H})$, and $0.52(\mathrm{~s}, 6 \mathrm{H}) ;{ }^{13} \mathrm{C} \mathrm{NMR}\left(\mathrm{CDCl}_{3}\right) \delta(\mathrm{ppm}): 142.80,134.58$, $127.68,127.35,58.10,51.42$, and $-1.80 ;{ }^{29} \mathrm{Si} N \mathrm{NMR}\left(\mathrm{CDCl}_{3}, 60{ }^{\circ} \mathrm{C}\right) \delta$ 
(ppm): -25.70 and -66.96; APCI-TOF-MS: $m / z=309.1202$. calcd for $\mathrm{C}_{14} \mathrm{H}_{23} \mathrm{NO}_{3} \mathrm{Si}_{2}: 309.1211[M]^{+}$. Crystal data for 1a: $\mathrm{C}_{14} \mathrm{H}_{23} \mathrm{NO}_{3} \mathrm{Si}_{2}$, from $\mathrm{CCl}_{4} / \mathrm{EtOH}, M=309.51$, Monoclinic, $P 2_{1} / n$ (No. 14), $a=6.613(2), b=$ 21.9028(4), $c=10.7275(2) \AA, \beta=94.0357(17)^{\circ}, V=1561.27(6) \AA^{3}, Z=4$ $T=93 \mathrm{~K}, \rho_{\text {calcd }}=1.317 \mathrm{~g} / \mathrm{cm}^{3}, R_{1}=0.0573(I>2.0 \sigma(I)), w R_{2}=0.1547$ (all data), GOF $=1.142$, CCDC No.: 985696.

Synthesis of Methyldiphenylsilylsilatrane (1b): Ethoxysilatrane (2.44 $\mathrm{g}, 12 \mathrm{mmol}$ ) was placed in a reaction flask. The flask was purged with nitrogen, and THF $(20 \mathrm{~mL})$ was added into the flask. Methyldiphenylsilyllithium [30] (ca. $1.0 \mathrm{M}$ solution in THF, $18 \mathrm{~mL}, 18 \mathrm{mmol}$ ) was added to the solution via a cannula. The reaction mixture was stirred at room temperature. After $20 \mathrm{~min}$, the reaction was quenched with a saturated $\mathrm{NH}_{4} \mathrm{Cl}$ solution and extracted with EtOAc. The organic layer was washed with brine, dried over anhydrous $\mathrm{Na}_{2} \mathrm{SO}_{4}$, filtered, and concentrated in vacuo to afford white solids. The solids were suspended in hexane $(5 \mathrm{~mL})$ and the suspension was then filtered off. The solids were washed on the filter paper with hexane to afford $\mathbf{1 b}(1.02 \mathrm{~g}, 2.75$ mmol, 23\%). Colorless solid. Mp 170-171 ${ }^{\circ} \mathrm{C}$. IR (neat): 1427, 1271 , 1108, 1067, 910, 748, 735, 700, $629 \mathrm{~cm}^{-1} .{ }^{1} \mathrm{H}$ NMR $\left(\mathrm{CDCl}_{3}\right) \delta(\mathrm{ppm})$ : 7.71-7.66 (m, 4H), 7.32-7.27 (m, 6H), $3.77(\mathrm{t}, \mathrm{J}=5.5 \mathrm{~Hz}, 6 \mathrm{H}), 2.76(\mathrm{t}, \mathrm{J}$ $=5.5 \mathrm{~Hz}, 6 \mathrm{H})$, and $0.57(\mathrm{~s}, 3 \mathrm{H}) ;{ }^{13} \mathrm{C} \mathrm{NMR}\left(\mathrm{CDCl}_{3}\right) \delta(\mathrm{ppm}): 140.91$, $135.47,127.83,127.35,57.95,51.33$, and $-2.87 ;{ }^{29} \mathrm{Si} \mathrm{NMR}\left(\mathrm{CDCl}_{3}\right.$, $\left.60{ }^{\circ} \mathrm{C}\right) \delta(\mathrm{ppm}):-26.56$ and -69.02 ; APCI-TOF-MS: $\mathrm{m} / \mathrm{z}=371.1360$. calcd for $\mathrm{C}_{19} \mathrm{H}_{25} \mathrm{NO}_{3} \mathrm{Si}_{2}$ : $371.1367[M]^{+}$. Crystal data for $\mathbf{1 b}$ $\mathrm{C}_{19} \mathrm{H}_{25} \mathrm{NO}_{3} \mathrm{Si}_{2}$, from 1,2-Dichloroethane/EtOH, $M=371.58$, Orthorhombic Pbca (No. 61) $a=11.4397(3), b=24.7612(6), c=13.1386(3) \AA, V=$ $3721.65(16) \AA^{3}, Z=8, T=93 \mathrm{~K}, \rho_{\text {calcd }}=1.326 \mathrm{~g} / \mathrm{cm}^{3}, R_{1}=0.0516(I>2.0$ $\sigma(I)), w R_{2}=0.1183$ (all data), GOF = 1.077, CCDC No.: 985697 .

Synthesis of Dimethyl(o-tolyl)silylsilatrane (1c): $\mathrm{Et}_{2} \mathrm{O}(15 \mathrm{~mL})$ and dichlorodimethylsilane $(60 \mathrm{mmol}, 9.0 \mathrm{~mL})$ were added to a reaction flask purged with nitrogen. The reaction mixture was cooled to $0{ }^{\circ} \mathrm{C}$. 2Methylphenylmagnesium bromide $(0.62 \mathrm{M}$ in THF, $81 \mathrm{~mL}, 50 \mathrm{mmol})$ was added to the solution at $0{ }^{\circ} \mathrm{C}$ via a cannula, which was warmed to room temperature. After the reaction mixture was stirred overnight, the resulting suspension was filtered off and washed on the filter with hexane to collect the filtrate. After evaporation of the solvent, chlorodimethyl(otolyl)silane was distilled under reduced pressure $\left(3\right.$ torr, $78{ }^{\circ} \mathrm{C}, 5.37 \mathrm{~g}$, $29.0 \mathrm{mmol}, 58 \%)$. Lithium wire $(500 \mathrm{mg}, 70 \mathrm{mmol})$ in oil was cut into 4 $\mathrm{mm}$ cubes with scissors. These lithium cubes were stirred vigorously for $10 \mathrm{~min}$ in hexane $(5 \mathrm{~mL})$ under nitrogen. The hexane was removed and the lithium was suspended in THF (15 mL). The mixture was stirred rapidly with chlorodimethyl(o-tolyl)silane $(3.0 \mathrm{~mL}, 18 \mathrm{mmol})$ at room temperature for $6 \mathrm{~h}$ to give a deep red solution of $\mathrm{Me}_{2}$ (o-tolyl)SiLi (ca. 1.0 M). Ethoxysilatrane $(2.44 \mathrm{~g}, 12 \mathrm{mmol})$ was placed in a reaction flask. The reaction flask was purged with nitrogen, and THF $(20 \mathrm{~mL})$ was added into the reaction flask. Dimethyl(o-tolyl)silyllithium (ca. $1.0 \mathrm{M}$ solution in THF, $18 \mathrm{~mL}, 18 \mathrm{mmol}$ ) was added to the solution via a cannula The reaction mixture was stirred at room temperature. After $30 \mathrm{~min}$, the reaction was quenched with a saturated $\mathrm{NH}_{4} \mathrm{Cl}$ solution and extracted with EtOAc. The organic layer was washed with brine, dried over anhydrous $\mathrm{Na}_{2} \mathrm{SO}_{4}$, filtered, and concentrated in vacuo to afford white solids. The solids were suspended in hexane $(5 \mathrm{~mL})$ and the suspension was then filtered off. The solids were washed on the filter paper with hexane to afford 1c (486 mg, $1.50 \mathrm{mmol}, 13 \%)$. Colorless solid. Mp 143$144^{\circ} \mathrm{C}$. IR (neat): $1453,1274,1110,1075,874,812,740,624,588 \mathrm{~cm}^{-1}$. ${ }^{1} \mathrm{H}$ NMR $\left(\mathrm{CDCl}_{3}\right) \delta(\mathrm{ppm}): 7.56(\mathrm{~d}, \mathrm{~J}=6.4 \mathrm{~Hz}, 1 \mathrm{H}), 7.17(\mathrm{t}, \mathrm{J}=7.8 \mathrm{~Hz}$, $1 \mathrm{H}), 7.13-7.07(\mathrm{~m}, 2 \mathrm{H}), 3.72(\mathrm{t}, J=5.5 \mathrm{~Hz}, 6 \mathrm{H}), 2.76(\mathrm{t}, J=5.5 \mathrm{~Hz}, 6 \mathrm{H})$, $2.52(\mathrm{~s}, 3 \mathrm{H})$, and $0.35(\mathrm{~s}, 6 \mathrm{H}) ;{ }^{13} \mathrm{C} \mathrm{NMR}\left(\mathrm{CDCl}_{3}\right) \delta(\mathrm{ppm}): 144.52,140.72$, $135.21,129.29,128.11,124.58,58.32,51.57,23.35$, and $-1.06 ;{ }^{29} \mathrm{Si}$ NMR $\left(\mathrm{CDCl}_{3}, 60^{\circ} \mathrm{C}\right) \delta(\mathrm{ppm}):-25.62$ and -65.51 ; APCl-TOF-MS: $\mathrm{m} / \mathrm{z}=$ 323.1352. calcd for $\mathrm{C}_{15} \mathrm{H}_{25} \mathrm{NO}_{3} \mathrm{Si}_{2}: 323.1367[\mathrm{M}]^{+}$.
Synthesis of Trimethylsilylsilatrane (1d): Ethoxysilatrane $(6.58 \mathrm{~g}, 30$ $\mathrm{mmol})$ and THF $(40 \mathrm{~mL})$ were added to a reaction flask under nitrogen Trimethylsilyllithium ${ }^{[31]}$ (ca. $0.24 \mathrm{M}$ in THF, $62 \mathrm{~mL}, 15 \mathrm{mmol}$ ) was added to the solution via a cannula. The reaction mixture was stirred overnight at room temperature. The reaction was quenched with a saturated $\mathrm{NH}_{4} \mathrm{Cl}$ solution and extracted with EtOAc. The organic layer was washed with brine, dried over anhydrous $\mathrm{Na}_{2} \mathrm{SO}_{4}$, filtered, and concentrated to afford white solids. The solids were suspended in hexane $(5 \mathrm{~mL})$ and were then filtered off. The solids were washed on the filter paper with hexane to afford $1 \mathrm{~d}(1.04 \mathrm{~g}, 4.2 \mathrm{mmol}, 28 \%)$. Colorless solid. Mp $171-174{ }^{\circ} \mathrm{C}$. IR (neat): $1110,1077,935,849,824,744,726,640,613 \mathrm{~cm}^{-1} .{ }^{1} \mathrm{H}$ NMR $\left(\mathrm{CDCl}_{3}\right) \delta(\mathrm{ppm}): 3.73(\mathrm{t}, \mathrm{J}=5.5 \mathrm{~Hz}, 6 \mathrm{H}), 2.76(\mathrm{t}, \mathrm{J}=5.5 \mathrm{~Hz}, 6 \mathrm{H})$, and $0.04(\mathrm{~s}, 9 \mathrm{H}) ;{ }^{13} \mathrm{C} \mathrm{NMR}\left(\mathrm{CDCl}_{3}\right) \delta(\mathrm{ppm}): 58.29,51.47$, and $-0.81 ;{ }^{29} \mathrm{Si}$ NMR $\left(\mathrm{CDCl}_{3}, 60{ }^{\circ} \mathrm{C}\right) \delta$ (ppm): -23.85 and -64.03 ; APCI-TOF-MS: $\mathrm{m} / \mathrm{z}=$ 247.1061. calcd for $\mathrm{C}_{9} \mathrm{H}_{21} \mathrm{NO}_{3} \mathrm{Si}_{2}: 247.1054$ [M]-

Synthesis of 1,1,2,2-Tetramethyl-1-phenyl-2-isopropoxydisilane: Ether $(100 \mathrm{~mL})$ and 1,2-dichloro-1,1,2,2-tetramethyldisilane $(30 \mathrm{mmol}$, $5.56 \mathrm{~mL}$ ) were added to a reaction flask purged with nitrogen. The reaction mixture was cooled to $0{ }^{\circ} \mathrm{C}$. $\mathrm{PhMgBr}\left(0.47 \mathrm{M}\right.$ in $\mathrm{Et}_{2} \mathrm{O}, 60 \mathrm{~mL}$, $28.2 \mathrm{mmol}$ ) was added. After stirring at $0{ }^{\circ} \mathrm{C}$ for $8 \mathrm{~h}$, the resulting suspension was filtered off and washed on the filter with hexane to collect the filtrate. After evaporation, 1-chloro-2-phenyl-1,1,2,2tetramethyldisilane was distilled under reduced pressure $\left(3\right.$ torr, $89^{\circ} \mathrm{C}$, $4.29 \mathrm{~g}, 18.7 \mathrm{mmol}, 62 \%)$. DMAP $(2.5 \mathrm{mmol}, 305.4 \mathrm{mg})$, imidazole $(6.0$ $\mathrm{mmol}, 408.5 \mathrm{mg}$ ), and 1-chloro-2-phenyl-1,1,2,2-tetramethyldisilane (5.0 $\mathrm{mmol}, 1.14 \mathrm{~mL}$ ) were placed in a reaction flask. The reaction flask was purged with nitrogen, and DMF $(25 \mathrm{~mL})$ was added. The reaction mixture was cooled to $0{ }^{\circ} \mathrm{C}$, and $i \mathrm{PrOH}(10 \mathrm{mmol}, 0.77 \mathrm{mmol})$ was added dropwise. The reaction mixture was stirred at room temperature for $3 \mathrm{~h}$ and was then quenched by addition of water. The reaction mixture was diluted with ether. The layers were separated, and the aqueous layer was extracted with ether. The organic extracts were washed with brine three times, dried over anhydrous $\mathrm{Na}_{2} \mathrm{SO}_{4}$, filtered, and concentrated in vacuo to afford a colorless liquid. The product was distilled under reduced pressure (2 torr, $\left.73-74{ }^{\circ} \mathrm{C}, 757 \mathrm{mg}, 3.0 \mathrm{mmol}, 60 \%\right)$. Colorless liquid. IR (neat): $1244,1120,1106,1018,876,825,786,763,731,679,633 \mathrm{~cm}^{-1}$. ${ }^{1} \mathrm{H}$ NMR $\left(\mathrm{CDCl}_{3}\right) \delta(\mathrm{ppm}): 7.53-7.48(\mathrm{~m}, 2 \mathrm{H}), 7.37-7.30(\mathrm{~m}, 3 \mathrm{H}), 3.87$ (septet, $J=5.9 \mathrm{~Hz}, 1 \mathrm{H}), 1.09(\mathrm{~d}, \mathrm{~J}=5.9 \mathrm{~Hz}, 6 \mathrm{H}), 0.39(\mathrm{~s}, 6 \mathrm{H})$, and 0.23 $(\mathrm{s}, 6 \mathrm{H}) ;{ }^{13} \mathrm{C} \mathrm{NMR}\left(\mathrm{CDCl}_{3}\right) \delta(\mathrm{ppm}): 139.40,134.04,128.59,127.92,66.05$, 25.96, 0.26, and $-3.34 ;{ }^{29} \mathrm{Si}$ NMR $\left(\mathrm{CDCl}_{3}, 60{ }^{\circ} \mathrm{C}\right) \delta(\mathrm{ppm}): 10.65$ and 25.08; APCI-TOF-MS: $\mathrm{m} / \mathrm{z}=251.1270$. calcd for $\mathrm{C}_{13} \mathrm{H}_{24} \mathrm{OSi}_{2}$ : 251.1282 $[M]^{-}$

Typical Procedure for Silylation of Electron-Rich and Neutral Aryl Chlorides: The reaction of $\mathbf{1 a}$ with 4-chloroanisole (Table 1, entry 1 ) is representative. $\mathrm{Pd}_{2}(\mathrm{dba})_{3}(0.015 \mathrm{mmol}, 13.7 \mathrm{mg})$ and SPhos $(0.045$ $\mathrm{mmol}, 18.5 \mathrm{mg}$ ) were added to a reaction flask. The reaction flask was purged with argon, and toluene $(0.5 \mathrm{~mL})$ was added. The reaction mixture was then stirred at room temperature for $10 \mathrm{~min}$. 4Chloroanisole $(0.50 \mathrm{mmol}, 71.2 \mathrm{mg})$ was added to the reaction flask and then the reaction mixture was stirred at room temperature for $5 \mathrm{~min}$. Dimethylphenylsilylsilatrane $(0.60 \mathrm{mmol}, 185.7 \mathrm{mg})$ and toluene $(1.0 \mathrm{~mL})$ were added. The reaction mixture was then stirred at $100{ }^{\circ} \mathrm{C}$ for $12 \mathrm{~h}$. The resulting mixture was diluted with AcOEt and passed through an alumina short column with copious washings with AcOEt. Chromatographic purification on silica gel by using AcOEt / hexane ( $1 /$ 40) as an eluent afforded $\mathbf{2 a}$ (108 $\mathrm{mg}, 0.444 \mathrm{mmol}$ ) in $89 \%$ yield.

Typical Procedure for Silylation of Electron-Deficient and Neutral Aryl Chlorides: The reaction of 1a with 1-chloro-4trifluoromethylbenzene (Table 1, entry 8) is representative. Under inert atmosphere, $\mathrm{Pd}\left(\mathrm{PtBu}_{3}\right)_{2}(0.025 \mathrm{mmol}, 12.8 \mathrm{mg})$ was added to a reaction flask. Toluene $(1.0 \mathrm{~mL})$ and 1-chloro-4-trifluoromethyltoluene $(0.50 \mathrm{mmol}$, 
$90.9 \mathrm{mg}$ ) were added to the reaction flask, and then the reaction mixture was stirred at room temperature for $5 \mathrm{~min}$. Dimethylphenylsilylsilatrane $(0.60 \mathrm{mmol}, 185.7 \mathrm{mg}$ ) was added, and the reaction mixture was then stirred at $100{ }^{\circ} \mathrm{C}$ for $10 \mathrm{~h}$. The resulting mixture was diluted with AcOEt and passed through a short alumina column with copious washings with AcOEt. Chromatographic purification on silica gel by using hexane as an eluent afforded $\mathbf{2 g}$ (140 mg, $0.499 \mathrm{mmol})$ in 99\% yield.

Products $\mathbf{2} \mathbf{a}^{[32]}, \mathbf{2} \mathbf{d}^{[33]}, \mathbf{2} \mathbf{f}^{[34]}, \mathbf{2} \mathbf{g}^{[32]}, \mathbf{2} \mathbf{h}^{[32]}, \mathbf{2}^{[32]}, \mathbf{3}^{[33]}, \mathbf{4}^{[35]}$, and $\mathbf{5}^{[36]}$ are known compounds and showed the identical spectra according to the literature.

\section{(4-tert-Butyldimethylsiloxyphenyl)dimethylphenylsilane}

Colorless oil. IR (neat): 1591, 1500, 1428, 1253, 1175, 1109, 911, 802, $774,699,653 \mathrm{~cm}^{-1} .{ }^{1} \mathrm{H}$ NMR $\left(\mathrm{CDCl}_{3}\right) \delta(\mathrm{ppm}): 7.53-7.48(\mathrm{~m}, 2 \mathrm{H}), 7.39$ $7.31(\mathrm{~m}, 5 \mathrm{H}), 6.83(\mathrm{~d}, \mathrm{~J}=8.3 \mathrm{~Hz}, 2 \mathrm{H}), 0.98(\mathrm{~s}, 9 \mathrm{H}), 0.52(\mathrm{~s}, 6 \mathrm{H})$, and 0.20 $(\mathrm{s}, 6 \mathrm{H}) ;{ }^{13} \mathrm{C}$ NMR $\left(\mathrm{CDCl}_{3}\right) \delta(\mathrm{ppm}): 156.84,138.92,135.76,134.30$, $129.74,129.11,127.90,119.79,25.83,18.34,-2.01$, and $-4.20 ;{ }^{29} \mathrm{Si}$ NMR ( $\mathrm{CDCl}_{3}$, room temperature) $\delta(\mathrm{ppm}): 20.62$ and -8.45 ; APCl-TOFMS: $m / z=343.1899$. calcd for $\mathrm{C}_{20} \mathrm{H}_{31} \mathrm{OSi}_{2}: 343.1908[M+\mathrm{H}]^{+}$

(4-Acetylaminophenyl)dimethylphenylsilane (2c): Colorless solid. Mp $115-116{ }^{\circ} \mathrm{C}$. IR (neat): 1669, 1590, 1530, 1371, 1322, 1292, 1247, 1112, 806, 778, 728, $701 \mathrm{~cm}^{-1} .{ }^{1} \mathrm{H}$ NMR $\left(\mathrm{CDCl}_{3}\right) \delta(\mathrm{ppm}): 7.59-7.44(\mathrm{~m}, 7 \mathrm{H})$, 7.39-7.32 (m, 3H), $2.17(\mathrm{~s}, 3 \mathrm{H})$, and $0.54(\mathrm{~s}, 6 \mathrm{H}) ;{ }^{13} \mathrm{C} \mathrm{NMR}\left(\mathrm{CDCl}_{3}\right) \delta$ (ppm): 168.67, 138.85, 138.35, 135.13, 134.25, 133.80, 129.22, 127.93, 119.31, 24.73, and -2.23 ; ${ }^{29} \mathrm{Si} \mathrm{NMR}\left(\mathrm{CDCl}_{3}\right.$, room temperature) $\delta(\mathrm{ppm})$ : -8.25; APCI-TOF-MS: $m / z=270.1316$. calcd for $\mathrm{C}_{16} \mathrm{H}_{20} \mathrm{NOSi} 270.1309$ $[\mathrm{M}+\mathrm{H}]^{+}$.

Dimethylphenyl(3-thienyl)silane (2e): Colorless oil. IR (neat): 1248 , 1105, 821, 795, 769, 730, 697, 655, $607 \mathrm{~cm}^{-1} .{ }^{1} \mathrm{H}$ NMR $\left(\mathrm{CDCl}_{3}\right) \delta(\mathrm{ppm})$ : 7.58-7.51 (m, 2H), 7.50-7.47 (m, 1H), 7.43-7.34 (m, 4H), $7.21(\mathrm{~d}, \mathrm{~J}=$ $4.6 \mathrm{~Hz}, 1 \mathrm{H})$, and $0.57(\mathrm{~s}, 6 \mathrm{H}) ;{ }^{13} \mathrm{C} \mathrm{NMR}\left(\mathrm{CDCl}_{3}\right) \delta(\mathrm{ppm}): 139.07,138.50$, $134.08,132.98,132.05,129.30,127.98,125.94$, and $-1.64 ;{ }^{29}$ Si NMR $\left(\mathrm{CDCl}_{3}, 60^{\circ} \mathrm{C}\right) \delta(\mathrm{ppm}):-12.42 ;$ APCl-TOF-MS: $\mathrm{m} / \mathrm{z}=217.0492$. calcd for $\mathrm{C}_{12} \mathrm{H}_{14} \mathrm{SSi}: 217.0502[\mathrm{M}-\mathrm{H}]^{-}$.

(3-Cyanophenyl)dimethylphenylsilane (2i): Colorless oil. IR (neat): 2227, 1428, 1391, 1250, 1111, 850, 829, 793, 774, 733, $701 \mathrm{~cm}^{-1} .{ }^{1} \mathrm{H}$ NMR $\left(\mathrm{CDCl}_{3}\right) \delta(\mathrm{ppm}): 7.78(\mathrm{~s}, 1 \mathrm{H}), 7.74-7.71(\mathrm{~m}, 1 \mathrm{H}), 7.66-7.62(\mathrm{~m}$, $1 \mathrm{H}), 7.53-7.49(\mathrm{~m}, 2 \mathrm{H}), 7.47-7.37(\mathrm{~m}, 4 \mathrm{H})$, and $0.59(\mathrm{~s}, 6 \mathrm{H}) ;{ }^{13} \mathrm{C}$ NMR $\left(\mathrm{CDCl}_{3}\right) \delta(\mathrm{ppm}): 140.86,138.32,137.77,136.53,134.20,132.58,129.79$ $128.48,128.23,119.28,112.29$, and $-2.57 ;{ }^{29} \mathrm{Si} \mathrm{NMR}\left(\mathrm{CDCl}_{3}\right.$, room temperature) $\delta$ (ppm): -7.08 ; APCI-TOF-MS: $m / z=238.1043$. calcd for $\mathrm{C}_{15} \mathrm{H}_{16} \mathrm{NSi}: 238.1047[M+\mathrm{H}]^{+}$

Dimethyl(3-nitrophenyl)phenylsilane (2j): Colorless oil. IR (neat): 1522 1346, 875, 833, 816, 778, 726, 700, 680, $662 \mathrm{~cm}^{-1} .{ }^{1} \mathrm{H}$ NMR $\left(\mathrm{CDCl}_{3}\right) \delta$ (ppm): $8.37(\mathrm{~s}, 1 \mathrm{H}), 8.21(\mathrm{~d}, \mathrm{~J}=8.4 \mathrm{~Hz}, 1 \mathrm{H}), 7.81(\mathrm{~d}, \mathrm{~J}=7.3 \mathrm{~Hz}, 1 \mathrm{H})$,

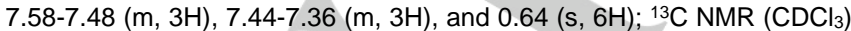
$\delta$ (ppm): 148.00, 141.58, 140.30, 136.49, 134.19, 129.83, 128.92, 128.61 128.25, 124.11, and $-2.52 ;{ }^{29} \mathrm{Si} \mathrm{NMR}\left(\mathrm{CDCl}_{3}\right.$, room temperature) $\delta(\mathrm{ppm})$ : -6.75; APCI-TOF-MS: $m / z=258.0944$. calcd for $\mathrm{C}_{14} \mathrm{H}_{16} \mathrm{NO}_{2} \mathrm{Si}: 258.0945$ $[\mathrm{M}+\mathrm{H}]^{+}$.

Dimethyl(4-pinacolatoborylphenyl)phenylsilane (2k): Colorless solid. Mp 87-94 ${ }^{\circ} \mathrm{C}$. IR (neat): 1357, 1139, 1075, 808, 776, 746, 732, 700, 656 $\mathrm{cm}^{-1} .{ }^{1} \mathrm{H}$ NMR $\left(\mathrm{CDCl}_{3}\right) \delta(\mathrm{ppm}): 7.79(\mathrm{~d}, \mathrm{~J}=7.8 \mathrm{~Hz}, 2 \mathrm{H}), 7.54(\mathrm{~d}, \mathrm{~J}=7.8$ $\mathrm{Hz}, 2 \mathrm{H}), 7.52-7.49(\mathrm{~m}, 2 \mathrm{H}), 7.38-7.31(\mathrm{~m}, 3 \mathrm{H}), 1.35(\mathrm{~s}, 12 \mathrm{H})$, and $0.55(\mathrm{~s}$, $6 \mathrm{H}) ;{ }^{13} \mathrm{C} \mathrm{NMR}\left(\mathrm{CDCl}_{3}\right) \delta$ (ppm): 142.01, 138.20, 136.27, 134.32, 134.03, $133.62,129.25,127.94,83.91,24.99$, and $-2.34 ;{ }^{29} \mathrm{Si} \mathrm{NMR}\left(\mathrm{CDCl}_{3}\right.$, room temperature) $\delta$ (ppm): -7.87 ; APCI-TOF-MS: $m / z=339.1960$. calcd for $\mathrm{C}_{20} \mathrm{H}_{28} \mathrm{BO}_{2} \mathrm{Si}_{2}: 339.1950[\mathrm{M}+\mathrm{H}]^{+}$

\section{Acknowledgements}

This work was supported by Grants-in-Aid from MEXT (Nos.: 24106721 "Reaction Integration" and 25107002 "Science of Atomic Layers") and from JSPS (Nos.: 24685007 (Young Scientists (A)), 23655037 and 26620081 (Exploratory Research)). K.M. and Y.Y. acknowledge fellowship from JSPS

\section{Keywords: Silylation • Palladium • Aryl Chloride •}

Transmetalation

[1] Books: a) T. Hiyama, in Organometallics in Synthesis, Third Manual (Ed: M. Schlosser), John Wiley \& Sons, Hoboken, 2013, Chapter 3; b) Science of Synthesis, Category 1, Vol. 4 (Ed. I. Fleming), Georg Thieme Verlag, Stuttgart, 2002, Chapter 4.4; c) M. A. Brook, Silicon in Organic, Organometallic, and Polymer Chemistry, Wiley, New York, 2000; d) Organosilicon Chemistry Set: From Molecules to Materials (Eds: N. Auner, J. Weis), Wiley-VCH, Weinheim, 1994-2005.

[2] a) E. Morita, K. Murakami, M. Iwasaki, K. Hirano, H. Yorimitsu, K. Oshima, Bull. Chem. Soc. Jpn. 2009, 82, 1012; b) K. Murakami, H. Yorimitsu, K. Oshima, J. Org. Chem. 2009, 74, 1415 and references cited therein; c) Ref 1a, Section 3.2.1.

[3] Hydrosilylation and related C-Si-bond-forming addition reactions: a) Hydrosilylation (Ed: B. Marciniec), Springer, Heidelberg, 2009; b) Ref 1a, Section 3.2.3.

[4] Activator-free palladium-catalyzed substitution reactions of organic halides with disilanes at very high temperatures: a) $\mathrm{H}$. Matsumoto, $\mathrm{S}$ Nagashima, K. Yoshihiro, Y. Nagai, J. Organomet. Chem. 1975, 85, C1; b) D. Azarian, S. S. Dua, C. Eaborn, D. R. M. Walton, J. Organomet. Chem. 1976, 117, C55; c) H. Matsumoto, K. Yoshihiro, S. Nagashima H. Watanabe, Y. Nagai, J. Organomet. Chem. 1977, 128, 409; d) H. Matsumoto, K. Shono, Y. Nagai, J. Organomet. Chem. 1981, 208, 145; e) C. Eaborn, R. W. Griffiths, A. Pidcock, J. Organomet. Chem. 1982, 225, 331; f) H. Matsumoto, M. Kasahara, I. Matsubara, M. Takahashi, T. Arai, M. Hasegawa, T. Nakano, Y. Nagai, J. Organomet. Chem. 1983 250, 99; g) P. Babin, B. Bennetau, M. Theurig, J. Dunoguès, J. Organomet. Chem. 1993, 446, 135

[5] Tsuji found that his very bulky phosphine ligand is effective in activatorfree silylation of aryl chloride: T. Iwasawa, T. Komano, A. Tajima, M. Tokunaga, Y. Obora, T. Fujihara, Y. Tsuji, Organometallics 2006, 25, 4665

[6] Palladium-catalyzed silylation of organic halides with disilanes with silicophilic activators: a) Y. Hatanaka, T. Hiyama, Tetrahedron Lett. 1987, 28, 4715; b) E. Shirakawa, T. Kurahashi, H. Yoshida, T. Hiyama, Chem. Commun. 2000, 1895; c) L. J. Gooßen, A.-R. S. Ferwanah, Synlett 2000, 1801; d) S. E. Denmark, J. M. Kallemeyn, Org. Lett. 2003, 5, 3483; e) E. McNeill, T. E. Barder, S. L. Buchwald, Org. Lett. 2007, 9 , 3785 ; f) Y. Minami, K. Shimizu, C. Tsuruoka, T. Komiyama, T. Hiyama, Chem. Lett. 2014, 43, 201.

[7] Activator-free palladium-catalyzed silylation of aroyl halides with disilanes: a) K. Yamamoto, S. Suzuki, J. Tsuji, Tetrahedron Lett. 1980, 21, 1653; b) J. D. Rich, J. Am. Chem. Soc. 1989, 111, 5886; c) T. E. Krafft, J. D. Rich, P. J. McDermott, J. Org. Chem. 1990, 55, 5430.

[8] Selected examples of silylation of organic halides with hydrosilanes: a) M. Murata, K. Suzuki, S. Watanabe, Y. Masuda, J. Org. Chem. 1997, 62, 8569; b) M. Murata, M. Ishikura, M. Nagata, S. Watanabe, Y. Masuda, Org. Lett. 2002, 4, 1843; c) M. Murata, Y. Masuda, J. Synth. Org. Chem., Jpn. 2010, 68, 845; d) Y. Yamanoi, J. Org. Chem. 2005, 70, 
9607; e) Y. Kurihara, Y. Yamanoi, H. Nishihara, Chem. Commun. 2013 49, 11275; f) Y. Yamanoi, H. Nishihara, J. Synth. Org. Chem., Jpn. 2009 67, 778; g) A. S. Manoso, P. DeShong, J. Org. Chem. 2001, 66, 7449; h) M. Izuka, Y. Kondo, Eur. J. Org. Chem. 2008, 1161; i) A. Hamze, O. Provot, M. Alami, J.-D. Brion, Org. Lett. 2006, 8, 931; j) D. Karshtedt, A T. Bell, T. D. Tilly, Organometallics 2006, 25, 4471.

[9] Representative examples of direct C-H silylation: a) W. A. Gustavson, P. S. Epstein, M. D. Curtis, Organometallics 1982, 1, 884; b) T. Sakakura T. Sodeyama, Y. Tokunaga, M. Tanaka. Chem. Lett. 1987, 16, 2211; c) F. Kakiuchi, K. Igi, M. Matsumoto, T. Hayamizu, N. Chatani, S. Murai, Chem. Lett. 2002, 31, 396; d) T. Ishiyama, K. Sato, Y. Nishio, N Miyaura, Angew. Chem. 2003, 115, 5504; Angew. Chem. Int. Ed. 2003 42, 5346; e) M. Murata, N. Fukuyama, J. Wada, S. Watanabe, Y Masuda, Chem. Lett. 2007, 36, 910; f) M. Tobisu, Y. Ano, N. Chatani, Chem. Asian J. 2008, 3, 1585; g) B. Lu, J. R. Falck, Angew. Chem. 2008, 120, 7618; Angew. Chem. Int. Ed. 2008, 47, 7508; h) J. F. Hartwig, Acc. Chem. Res. 2012, 45, 864; i) T. Ishiyama, T. Saiki, E. Kishida, I. Sasaki, H. Ito, N. Miyaura, Org. Biomol. Chem. 2013, 11, 8162 and references cited therein.

[10] Rhodium-catalyzed activator-free silylation of nitrile with disilanes: a) $M$. Tobisu, Y. Kita, N. Chatani, J. Am. Chem. Soc. 2006, 128, 8152; b) M. Tobisu, Y. Kita, Y. Ano, N. Chatani, J. Am. Chem. Soc. 2008, 130, 15982.

[11] Rhodium-catalyzed activator-free silylation of fluoroarenes with disilanes: Y. Ishii, N. Chatani, S. Yorimitsu, S. Murai, Chem. Lett. 1998 27, 157

[12] Ni/Cu-catalyzed fluoride-promoted silylation of aryl pivalates with silylborane: C. Zarate, R. Martin, J. Am. Chem. Soc. 2014, 136, 2236.

[13] Eaborn and Mori/Shibasaki reported palladium-catalyzed silylation with silylstannane that has a weaker Si-Sn bond under base-free conditions. However, their attempts resulted in low yields of the expected arylsilanes or undesired stannylation. a) M. Mori, N. Kaneta, M. Shibasaki, J. Org. Chem. 1991, 56, 3486; b) H. Azarian, C. Eaborn, A Pidcock, J. Organomet. Chem. 1981, 215, 49.

[14] Reviews on atranes: a) J. K. Puri, R. Singh, V. K. Chahal, Chem. Soc. Rev. 2011, 40, 1791; b) J. G. Verkade, Coord. Chem. Rev. 1994, 137, 233; c) J. G. Verkade, Acc. Chem. Res. 1993, 26, 483.

[15] Atranes in activator-free cross-coupling: a) E. Vedejs, A. R. Haight, W. O. Moss, J. Am. Chem. Soc. 1992, 114, 6556; b) M. S. Jensen, C. Yang Y. Hsiao, N. Rivera, K. M. Wells, J. Y. L. Chung, N. Yasuda, D. L. Hughes, P. J. Reider, Org. Lett. 2000, 2, 1081; c) H. L. Sebahar, K. Yoshida, L. S. Hegedus, J. Org. Chem. 2002, 67, 3788; d) L. Li, C.-Y. Wang, R. Huang, M. R. Biscoe, Nature Chem. 2013, 5, 607; e) M. Kosugi, T. Tanji, Y. Tanaka, A. Yoshida, K. Fugami, M. Kameyama, T. Migita, J. Organomet. Chem. 1996, 508, 255.

[16] Silatranes and germatranes in base-promoted cross-coupling: a) S. Riggleman, P. DeShong, J. Org. Chem. 2003, 68, 8106; b) R. R. Pidaparthi, M. E. Welker, C. S. Day, M. W. Wright, Org. Lett. 2007, 9, 1623; c) I. Peñafiel, I. M. Pastor, M. Yus, M. A. Esteruelas, M. Oliván, E. Oñate, Eur. J. Org. Chem. 2011, 7174; d) J. W. Faller, R. G. Kultyshev Organometallics 2002, 21, 5911.

[17] Despite its simple structure, synthesis of $\mathrm{Me}_{2} \mathrm{PhSi}-\mathrm{Si}(\mathrm{OMe})_{3}$ is unknown. Our attempts to synthesize $\mathrm{Me}_{2} \mathrm{PhSi}-\mathrm{Si}(\mathrm{OMe})_{3}$ from $\mathrm{Si}(\mathrm{OMe})_{4}$ and $\mathrm{Me}_{2} \mathrm{PhSi}$ i failed.
[18] Y. Zhang, F. Cervantes-Lee, K. H. Pannell, Organometallics 2002, 21, 5859

[19] a) D. S. Surry, S. L. Buchwald, Angew. Chem. 2008, 120, 6438; Angew. Chem. Int. Ed. 2008, 47, 6338; b) R. Martin, S. L. Buchwald, Acc Chem. Res. 2008, 41, 1461.

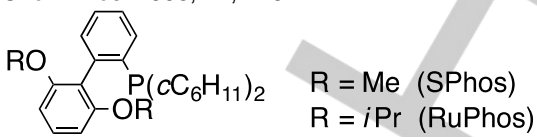

[20] a) S. Otsuka, T. Yoshida, M. Matsumoto, K. Nakatsu, J. Am. Chem. Soc 1976, 98, 5850; b) J. P. Stambuli, M. Buehl, J. F. Hartwig, J. Am. Chem. Soc. 2002, 124, 9346; c) A. F. Littke, L. Schwarz, G. C. Fu, J. Am Chem. Soc. 2002, 124, 6343.

[21] We assume that the strongly electron-donating nature of $\mathrm{PtBu}_{3}$ would enhance the Lewis basicity of the chloride of $\operatorname{ArPdCl}\left(\mathrm{PtBu}_{3}\right)$. See the mechanistic discussion.

[22] Attempted silylation of 1-bromo-4-trifluoromethylbenzene under condt $B$ as well as that of 1-bromo-4-chlorobenzene under both condt. A and $B$ resulted in recovery of the starting materials.

[23] Frisch, M. J. et al. Gaussian 09, rev. C.01; Gaussian, Inc.; Wallingford, CT, 2010. For full citation, see Supporting Information.

[24] Computational perspectives on the mechanisms of Pd-catalyzed crosscoupling reactions were summarized nicely: a) M. García-Melchor, A. A. C. Braga, A. Lledós, G. Ujaque, F. Maseras, Acc. Chem. Res. 2013, 46 2626; b) L. Xue, Z. Lin, Chem. Soc. Rev. 2010, 39, 1692

[25] The calculated bond dissociation energies of $\mathrm{H}_{3} \mathrm{Si}-\mathrm{Cl}$ and $\mathrm{H}_{3} \mathrm{Si}-\mathrm{Br}$ at 0 $\mathrm{K}$ at the $\operatorname{CCSD}(\mathrm{T}) / \mathrm{aVTZ}-\mathrm{PP}$ level are 453 and $384 \mathrm{kJmol}^{-1}$, respectively. a) D. J. Grant, D. A. Dixon, J. Phys. Chem. A 2009, 113, 3656. Also see: b) R. Becerra, R. Walsh, in The Chemistry of Organic Silicon Compounds (Eds. Z. Rappoport, Y. Apeloig); John Wiley \& Sons: Chichester, 1998; Vol. 2, Chapter 4, p 153.

[26] A similar trend was observed in the Stille reactions: a) A. Ariafard, Z. Lin, I. J. S. Fairlamb, Organometallics 2006, 25, 5788; b) A. L. Casado, P. Espinet, J. Am. Chem. Soc. 1998, 120, 8978.

[27] SHELXL-97 and SHELXS-97, program for refinement of crystal structures from diffraction data, University of Goettingen, Goettingen (Germany); G. Sheldrick, T. Schneider, Methods Enzymol. 1997, 277 319.

[28] I. Iovel, L. Golomba, J. Popelis, S. Grinberga, E. Lukevics, Chem. Heterocyclic Compounds 1999, 35, 1059

[29] S. Naito, M. Escobar, P. R. Kym, S. Liras, S. F. Martin, J. Org. Chem. 2002, 67, 4200.

[30] X.-J. Han, M. Yao, C.-D. Lu, Org. Lett. 2012, 14, 2906

[31] H. Azuma, K. Okano, H. Tokuyama, Chem. Lett. 2011, 40, 959

[32] M. Uchiyama, Y. Kobayashi, T. Furuyama, S. Nakamura, Y. Kajihara, T. Miyoshi, T. Sakamoto, Y. Kondo, K. Morokuma, J. Am. Chem. Soc 2008, 130, 472

[33] Y. Yamanoi, H. Nishihara, Tetrahedron Lett. 2006, 47, 7157.

[34] K. Murakami, K. Hirano, H. Yorimitsu, K. Oshima, Angew. Chem. 2008 120, 591; Angew. Chem. Int. Ed. 2008, 47, 5833.

[35] U. Wannagat, R. Schrader, J. Organomet. Chem. 1988, 341, 95.

[36] B. M. Trost, J. Yoshida, Tetrahedron Lett. 1983, 24, 4895. 


\section{FULL PAPER}

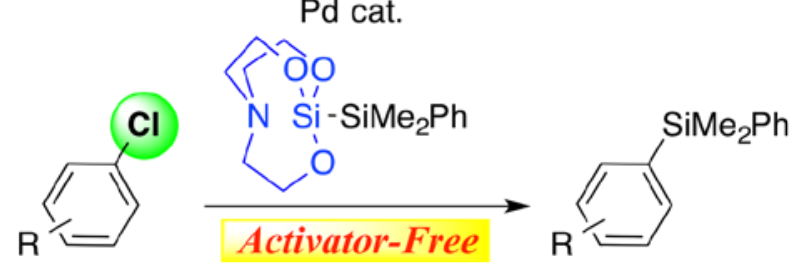

Palladium-catalyzed silylation of aryl chlorides with silylsilatranes proceeds under activator-free conditions, hence displaying wide functional group compatibility to allow boryl and siloxy groups to survive. Experimental and computational studies have revealed that the chloride on palladium plays important roles for smooth transmetalation from silylsilatranes to arylpalladium chloride is facilitated by strong interaction between the Lewis acidic silicon and the chloride.
Y. Yamamoto, H. Matsubara, ${ }^{\star} K$.

Murakami, H. Yorimitsu, ${ }^{\star}$ and $A$. Osuka

Page No. - Page No.

Activator-Free Palladium-Catalyzed Silylation of Aryl Chlorides with Silylsilatranes 